NUT OF LAW

DIGITAL REPOSITORY

Faculty Book Display Case

School of Law

$3-2012$

\title{
Humanitarian Law in Action within Africa
}

Jennifer Moore

University of New Mexico - School of Law, moore@law.unm.edu

Follow this and additional works at: https://digitalrepository.unm.edu/law_facbookdisplay

Part of the Human Rights Law Commons, and the International Humanitarian Law Commons

\section{Recommended Citation}

Moore, Jennifer. "Humanitarian Law in Action within Africa." (2012): 384 Pages. https:// digitalrepository.unm.edu/ law_facbookdisplay/37

This Book is brought to you for free and open access by the School of Law at UNM Digital Repository. It has been accepted for inclusion in Faculty Book Display Case by an authorized administrator of UNM Digital Repository. For more information, please contact amywinter@unm.edu.

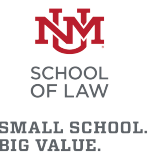




\section{HUMANITARIAN LAW IN ACTION WITHIN AFRICA}

Jennifer Moore

\section{OXFORD




\section{OXFORD \\ UNIVERSITY PRESS}

Oxford University Press, Inc., publishes works that further Oxford University's objective of excellence in research, scholarship, and education.

Oxford New York

Auckland Cape Town Dar es Salaam Hong Kong Karachi Kuala Lumpur Madrid Melbourne Mexico City Nairobi New Delhi Shanghai Taipei Toronto

With offices in

Argentina Austria Brazil Chile Czech Republic France Greece Guatemala Hungary Italy Japan Poland Portugal Singapore South Korea Switzerland Thailand Turkey Ukraine

Vietnam

Copyright (C) 2012 by Oxford University Press, Inc.

Published by Oxford University Press, Inc.

198 Madison Avenue, New York, New York 10016

Oxford is a registered trademark of Oxford University Press

Oxford University Press is a registered trademark of Oxford University Press, Inc.

All rights reserved. No part of this publication may be reproduced, stored in a rewieval system, or transmitted, in any form or by any means, electronic, mechanical, photocopying, recording, or otherwise, without the prior permission of Oxford University Press, Inc.

Library of Congress Cataloging-in-Publication Data

Moore, Jennifer, 1961-

Humanitarian law in action within Africa / Jennifer Moore.

p. $\mathrm{cm}$.

Includes bibliographical references and index.

ISBN 978-0-19-985696-1 (hardback: alk. paper)

1. Humanitarian law. 2. Humanitarian law-Africa. I. Title.

KZ6471.M66 2012

341.6'7096-dc23

2011042322

\section{1}

Printed in the United States of America on acid-free paper

\section{Note to Readers}

This publication is designed to provide accurate and authoritative information in regard to the subject matter covered. It is based upon sources believed to be accurate and reliable and is intended to be current as of the time it was written. It is sold with the understanding that the publisher is not engaged in rendering legal, accounting, or other professional services. If legal advice or other expert assistance is required, the services of a competent professional person should be sought. Also, to confirm that the information has not been affected or changed by recent developments, traditional legal research techniques should be used, including checking primary sources where appropriate.

(Based on the Declaration of Principles jointly adopted by a Committee of the American Bar Association and a Committee of Publishers and Associations.)

You may order this or any other Oxford University Press publication by visiting the Oxford University Press website at www.oup.com 
To my parents

Jonathan and Katherine A. Moore 


\section{CONTENTS}

Acknowledgments ix

Introduction 1

PART I: International Legal Rules for Conflict Resolution

1. The Human Fundamentals of International Law 13

2. Humanitarian Law: The Law of Armed Conflict 45

3. Human Rights Law: The Law of Human Dignity 75

4. International Criminal Law: Accountability for Crimes of War and Crimes Against Humanity 123

5. International Refugee Law: Protection for Individuals Fleeing Persecution and Armed Conflict 153

\section{PART II: Humanitarian Law and Post-conflict}

\section{Reconstruction in Africa}

6. Tools for Implementing Humanitarian Law: Courts, Troops, the Media, Development, and Communities

7. Beyond Juba in Uganda: Reconciling Restorative and Retributive Justice 209

8. After Lomé in Sierra Leone: The Special Court and National Reconciliation 241

9. After Arusha in Burundi: Disarming the Heart to Disarm the Body 283

Conclusion $\quad 323$

Index 335 


\section{ACKNOWLEDGMENTS}

This book is a kind of tapestry woven from threads that bind me to fellow travelers and kindred spirits on both sides of the Atlantic Ocean. I am particularly grateful for the support of my colleagues and students at the University of New Mexico School of Law, the scholars and human rights defenders I met and interviewed in Uganda, Burundi and Sierra Leone, my editing team at Oxford University Press, and my home team of family and friends. Back in 2008, Kevin Pendergast, OUP Senior Acquisitions Editor, encouraged me to spin an idea about the relationship between punitive and restorative justice in post-conflict African countries into a book proposal. His enthusiasm, flexibility and expertise launched the book and helped me keep it afloat throughout the research and writing process. Without Kevin, this project would never have been started.

Thanks first to my UNM colleagues: to my students Heba Atwa, Brianne Bigej, Greg Cole, Kameron Kramer, and Sophia Lane, who provided inspiration, sounding boards and research assistance, as needed; to Ernesto Longa, law librarian par excellence, for his zeal in locating essential books and articles, peace accords and national constitutions; to Nancy Harbert and Carolyn Gonzales, our in-house journalists, for reporting on the project; to my Dean Kevin Washburn, for supporting not one but two research trips to Africa in one year; to my fellow law profs Jim Ellis, Chris Fritz, Laura Gomez, Fred Hart, Nathalie Martin and Liz Rapaport, for talking me through the various stages of writing process; to Prof. Norman Bay, for sharing his expertise on international criminal law and critiquing Chapter 4; to Dr. Steve Bishop in Africana Studies for introducing me to child soldier narratives and reviewing the chapter on Sierra Leone; and to Dr. Felipe Gonzales in Sociology for helping me think about humanitarian law as a tool of social change and for editing the entire manuscript.

I owe a great intellectual and moral debt to the Ugandans, Burundians and Sierra Leoneans working in the field of humanitarian action and transformative justice in their countries. This book is meant to honor their commitment, their insights and their perseverance. For their efforts during 
my trip to Kampala in March of 2010, I would like to thank especially Rachel Odoi-Musoke, of the Ugandan Government's Justice, Law and Order Sector; Dr. Joseph Oloka-Onyango, Zahara Nampewo and Busingye Kabumba of the Human Rights and Peace Centre at Makerere University School of Law; and Moses Okello of the Beyond Juba Project. For their time and counsel during my visit to Burundi in 2010, thanks, merci and murakoze to Pie Ntakarutimana and Alexis Sinduhije, human rights defenders and pro-democracy activists; and Charles Ndayiziga of the Centre d'Alerte et Prévention de Conflits. For teaching me about Sierra Leone's political development, thanks to Dr. Jimmy Kandeh of the University of Richmond. For sharing their musical narratives of flight and exile, and for allowing me to use their song lyrics as chapter introductions, thanks to the Sierra Leone Refugee All Stars. For broadening my experience in Sierra Leone in October of 2010, thanks to Thomas Mark Turay, Mary Turay, Francis Massaquoi, Agnes Jattu Carew-Bah, Mohamed Kamara and all their colleagues at the Centre for Development and Peace Education in Mayagba, Bombali District; Joseph Sesay of the Centre for Accountability and the Rule of Law; John Caulker and Sheku Koroma of Fambul Tok; and Binta Mansaray, Registrar, and her staff at the Special Court for Sierra Leone. Special appreciation to Ibrahim George, Officer-in-Charge of the Freetown office of the International Committee of the Red Cross, for his dedication to humanitarian action as a global movement.

Throughout my research and during my trips to Kampala, Bujumbura and Freetown, I also met with members of the international community, who shared their insights on post-conflict reconstruction in Africa. I am especially grateful to Maud Roure, Burundi desk officer for Interpeace, who welcomed me to a peace conference supported by her organization in Bujumbura; Prof. Joel Samuels, who invited me to participate in a conference on Sierra Leone at the University of South Carolina; and Kassie Mcllvaine, who connected me to her colleagues in Burundi. Thanks also to the United Nations Peacebuilding Office in Freetown, led by Michael von der Schulenburg; the Sierra Leone delegation of United Nations High Commissioner for Refugees; Anne-Marie Callan, the Irish Chargé d'Affaires in Sierra Leone; Aitor Sanchez Lacomba, head of the Freetown delegation of the International Rescue Committee; and the Kampala, Bujumbura and Freetown delegations of the International Committee of the Red Cross. Geoff Loane, ICRC Delegate in London, deserves special mention for linking me to the ICRC offices in all three countries. ICRC kindled my interest in humanitarian law back in law school, and continues to inspire my engagement in the field of transitional justice.

My family members and dear friends all contributed to the writing of this book, intellectually and emotionally. My gratefulness to them goes 
beyond words. My godfathers Thomas Thornton and Dismas Mdachi form a bridge between the land of my birth and the land of my work. My daughter Kyra accompanied me to Sierra Leone and with my father and sister Joan read drafts of individual chapters. My friends Dana Bell, Janet Buck and Jim Vogele reviewed portions of the text. My mother, sister Joss, brother Charley and my daughter Tessa sent me off to Africa and welcomed me home, as they have many times. Felipe read every word of the manuscript, and without him this book would never have been finished. 